7. Reprod. Fert. (1969) 19, 73-86

\title{
NUMBERS OF SPERMATOZOA IN THE GENITAL TRACT AFTER ARTIFICIAL INSEMINATION OF PROGESTAGEN-TREATED EWES
}

\author{
T. D. QUINLIVAN* AND T. J. ROBINSON \\ Department of Animal Husbandry, University of Sydney, Australia
}

(Received 20th May 1968, revised 3rd September 1968)

\begin{abstract}
Summary. An experiment is described in which spermatozoa were recovered from genital tracts of ewes either at the first oestrus following progestagen synchronization or at a normal oestrus.

Recoveries 1, 12, 24, 36 and $48 \mathrm{hr}$ after the insemination of $500 \times 10^{6}$ spermatozoa show that synchronization with intravaginal sponges impregnated with the synthetic progestagen $17 \alpha$-acetoxy-9 $\alpha$-fluoro-11 $\beta$ hydroxypregn-4-ene-3,20-dione (Cronolone, Searle) alters the numbers and distribution of spermatozoa throughout the female genital tract at the first oestrus after treatment.

One hour after insemination the total numbers of spermatozoa recovered, and their distribution between the various regions of the tract, differed little between progestagen-treated and untreated ewes. Thereafter the numbers recovered from treated ewes were significantly fewer than from untreated, and their distribution differed. Significant differences appeared in the vagina at $12 \mathrm{hr}$ and in the cervix and uterus at $24 \mathrm{hr}$ and thereafter this difference was maintained. The pattern in the Fallopian tubes followed that of the uterus. At $24 \mathrm{hr}$ the mean numbers of tubal spermatozoa recovered were: synchronized-900; non-synchronized-8200 $(P<0.001)$.

Both transport and survival of spermatozoa may be deleteriously affected in the reproductive tract of the progestagen-treated ewe.
\end{abstract}

\section{INTRODUCTION}

Two authors (Hancock, 1962; Anon., 1963) have postulated that an alteration in the pattern of distribution of spermatozoa in the female reproductive tractand hence in the numbers available for fertilization-may cause the lowered fertility often observed following progestagen treatment for the synchronization of oestrus in sheep and cattle. Experimental evidence for this was presented by the authors (Quinlivan \& Robinson, 1967), who found that the pattern of sperm recovery from the Fallopian tubes of the ewe was altered at the first

* Present address: N.Z. Romney Survey, Box 231, Feilding, New Zealand. 
post-withdrawal oestrus following synchronization with intravaginal sponges

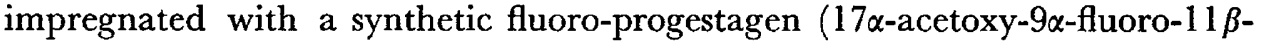
hydroxypregn-4-ene-3,20-dione; Cronolone, Searle). Highly significant differences were obtained $24 \mathrm{hr}$ after insemination-the approximate time of ovulation and fertilization in the ewe. Further, the insemination of numbers of spermatozoa within the range 80 to 500 million had little effect on the numbers recovered from the Fallopian tubes or on the fertilization rate of ova.

As the availability of spermatozoa in the Fallopian tubes is determined by the population in other divisions of the tract (Mattner, 1963, 1966), an experiment was conducted at the McCaughey Memorial Institute, Jerilderie, N.S.W., in January and February, 1967, to determine in which segment failure of transport, or survival, takes place, and the time relationships involved.

\section{MATERIALS AND METHODS}

\section{Experimental conditions}

One hundred and fifty 6-year-old ewes, plus two entire and five vasectomized rams were available. Of these, fifty progestagen-treated and fifty untreated ewes in oestrus were required.

Sixty ewes were treated for 16 days with intravaginal polyurethane sponges, $3.5 \mathrm{~cm}$ in diameter and impregnated, in the laboratory, with $30 \mathrm{mg}$ Cronolone (Robinson, 1965).

Fifty-four of the sixty progestagen-treated ewes (90\%) exhibited oestrus: fifty were incorporated into the experiment.

Sponges were inserted into the first group of five treated ewes on 18th January and thereafter at the rate of five every other day for 24 days.

The fifty untreated ewes were drawn from the remaining flock of ninety, as they exhibited oestrus.

Vasectomized rams, fitted with sire-sine harnesses and crayons, were joined with the ewes on 3rd February, the day the sponges were withdrawn from the first group of treated animals. Following removal of the sponges, treated and untreated ewes were run together and were inspected for oestrus twice daily at 06.00 and 18.00 hours. Oestrous ewes were inseminated as soon as detected, and were rotationally allocated into one of five groups, depending on the time of slaughter following insemination.

Inseminations were into the external cervical os and, to avoid any undue excitement in the period between insemination and slaughter, the ewes were run in a yard adjacent to the shed.

In order to check the relative times of insemination, examinations were made of the ovaries for follicular activity and of tubal flushings for number and stage of development of ova.

On each occasion of insemination, semen was collected from the two rams by using an artificial vagina. Each sample was examined for density and motility and the ejaculates pooled, the number of spermatozoa $/ \mathrm{ml}$ estimated by haemocytometer counts, and the volume required to provide $500 \times 10^{6}$ spermatozoa determined. All ewes were inseminated with undiluted semen, all samples of which reached a minimum grading of 4 for both density and motility (Ožin, 
1956). This represents semen containing at least $2500 \times 10^{6}$ spermatozoa $/ \mathrm{ml}$, of which at least $80 \%$ are motile.

\section{Recovery of spermatozoa}

Immediately after slaughter at a local abattoir, the abdomen was opened and the genital tract exteriorized. The vagina, cervix, uterus, and isthmus and ampulla of the Fallopian tubes were clamped or ligatured at their respective extremities. The entire tract was then removed and the separate divisions were wrapped in tissue towelling and plastic, and transported to the laboratory. The vagina, cervix, uterus, isthmus and ampulla were dissected free of their attachments and flushed, in that order, into appropriately labelled glass vials with calcium-free Krebs Ringer diluent. A standard method of dissection and flushing was used throughout, and scrupulous attention was paid to the cleanliness of instruments, glassware and personal hygiene. The volume of Krebs Ringer diluent was $10 \mathrm{ml}$ for the vagina, cervix and uterus, and $2 \mathrm{ml}$, followed by $1.5 \mathrm{ml}$ of air, for the isthmus and ampulla. The two isthmic and two ampullary flushings from the same ewe were pooled. All collections were immediately frozen to $-10^{\circ} \mathrm{C}$. The time from slaughter to completion of flushing, for any one ewe, ranged from $40 \mathrm{~min}$ to $2 \mathrm{hr}$, depending on the number of genital tracts to be examined.

Two techniques were used for the examination of flushings from the vagina, cervix and uterus.

1. Following thawing and thorough mixing of the 10-ml flushings, six haemocytometers were filled by Pasteur pipette, by the following method. Each chamber of the first haemocytometer was filled from the pipette and the residue returned to the vial. The contents of the vial were re-mixed and a second sample taken, and the procedure repeated until all six haemocytometers were filled. The numbers of spermatozoa in each haemocytometer were counted using the standard technique for white blood cells, with an Improved Neubauer ruling, and the mean for the six haemocytometers was determined. The total volume of the flushing was measured and the estimated number of spermatozoa present in the collection was calculated.

2. When less than twelve spermatozoa were counted in the total of the six haemocytometers (mean <2), a second count was made using the following technique. The flushing was thoroughly mixed and stained with congo rednigrosin stain $(3 \% \mathrm{w} / \mathrm{v}$ congo red; $5 \% \mathrm{w} / \mathrm{v}$ nigrosin; sodium citrate buffer) and $0.3-\mathrm{ml}$ aliquots were deposited on to each of six slides. A $20 \times 40 \mathrm{~mm}$ glass coverslip, pillared by Vaseline at six points, was lowered gently on to each sample. The slides were allowed to settle for 15 to $20 \mathrm{~min}$, when the numbers of spermatozoa were counted in four horizontal traverses at $\times 400$ magnification. From these counts the estimated number of spermatozoa in each flushing was calculated.

Flushings from the Fallopian tubes were thawed and stained by adding one drop of congo red-nigrosin stain. After thorough mixing, the total volume of the sample was distributed evenly on to six slides as described above and counted in the same manner. These counts represented one-twelfth of the total area of each slide. Multiplication by twelve of the total number counted on the six 
slides gave an estimate of the total number of spermatozoa recovered for each ewe.

\section{Experimental design}

The experiment had the following factorial design:

$$
\text { Comparison }
$$

1. Synchronization of oestrus

\section{Description}

Synchronized versus non-synchronized

(First oestrus)

(Untreated)
Factors

2

2. Time of slaughter (hr after insemination) 1 versus 12 versus 24 versus 36 versus 48 hr 5

$$
2 \times 5 ; n=10 ; \mathcal{N}=100
$$

Analyses of variance were conducted on the GSIRO GDC-3600 computer on the $\log _{10}$ numbers of spermatozoa counted (plus one to deal with zero values).

\section{RESULTS}

Relative stage of oestrus of synchronized and non-synchronized ewes

Both classes of ewes were inseminated at comparable times, judged by (a) the data for ewes with large follicles or which had ovulated shortly before slaughter (Table 1), and (b) the number of ova recovered. Of sixty-nine ova shed, thirty-seven $(59.9 \%$ ) were recovered, all from the ampulla, nineteen from synchronized and eighteen from untreated ewes. Of these, three were cleaving, at the two-cell stage.

\section{TABLE 1}

NUMBER OF EWES WITH LARGE FOLLICLES ( $>5$ MM) OR WHICH HAD

\begin{tabular}{|c|c|c|c|c|c|c|}
\hline \multirow[b]{2}{*}{$\begin{array}{c}\text { Time of } \\
\text { slaughter } \\
\text { (hr after } \\
\text { insemination) }\end{array}$} & \multicolumn{3}{|c|}{ Non-synchronized-controls } & \multicolumn{3}{|c|}{ Synchronized-first oestrus } \\
\hline & $\begin{array}{c}\text { Total } \\
\text { ewes } \\
\text { examined }\end{array}$ & $\begin{array}{l}\text { Recently } \\
\text { ovulated }\end{array}$ & $\begin{array}{c}\text { With large } \\
\text { follicles } \\
(>5 \mathrm{~mm})\end{array}$ & $\begin{array}{c}\text { Total } \\
\text { etwes } \\
\text { examined }\end{array}$ & $\begin{array}{l}\text { Recently } \\
\text { ovulated }\end{array}$ & $\begin{array}{c}\text { With large } \\
\text { follicles } \\
(>5 \mathrm{~mm})\end{array}$ \\
\hline $\begin{array}{r}1 \\
12 \\
24 \\
36 \\
48\end{array}$ & $\begin{array}{l}10 \\
10 \\
10 \\
10 \\
10\end{array}$ & $\begin{array}{r}0 \\
1 \\
10 \\
9 \\
10\end{array}$ & $\begin{array}{l}8 \\
7 \\
0 \\
1 \\
0\end{array}$ & $\begin{array}{l}10 \\
10 \\
10 \\
10 \\
10\end{array}$ & $\begin{array}{r}0 \\
1 \\
9 \\
9 \\
10\end{array}$ & $\begin{array}{l}8 \\
6 \\
1 \\
1 \\
0\end{array}$ \\
\hline Total & 50 & 30 & 16 & 50 & 29 & 16 \\
\hline
\end{tabular}
REGENTLY OVULATED WHEN EXAMINED AT SLAUGHTER

\section{Numbers of spermatozoa recovered}

Table 2 shows the estimated mean numbers of spermatozoa recovered from the various divisions of the tract at the five intervals of time. The data are presented in two ways, namely (a) arithmetic means based on the actual numbers counted, and (b) corrected means based on the $\log _{10}$ value for each count, as used in the analysis of variance. These latter values are used for the construction of Text-figs. 1 to 3 . Table 3 presents two split-plot analyses of 


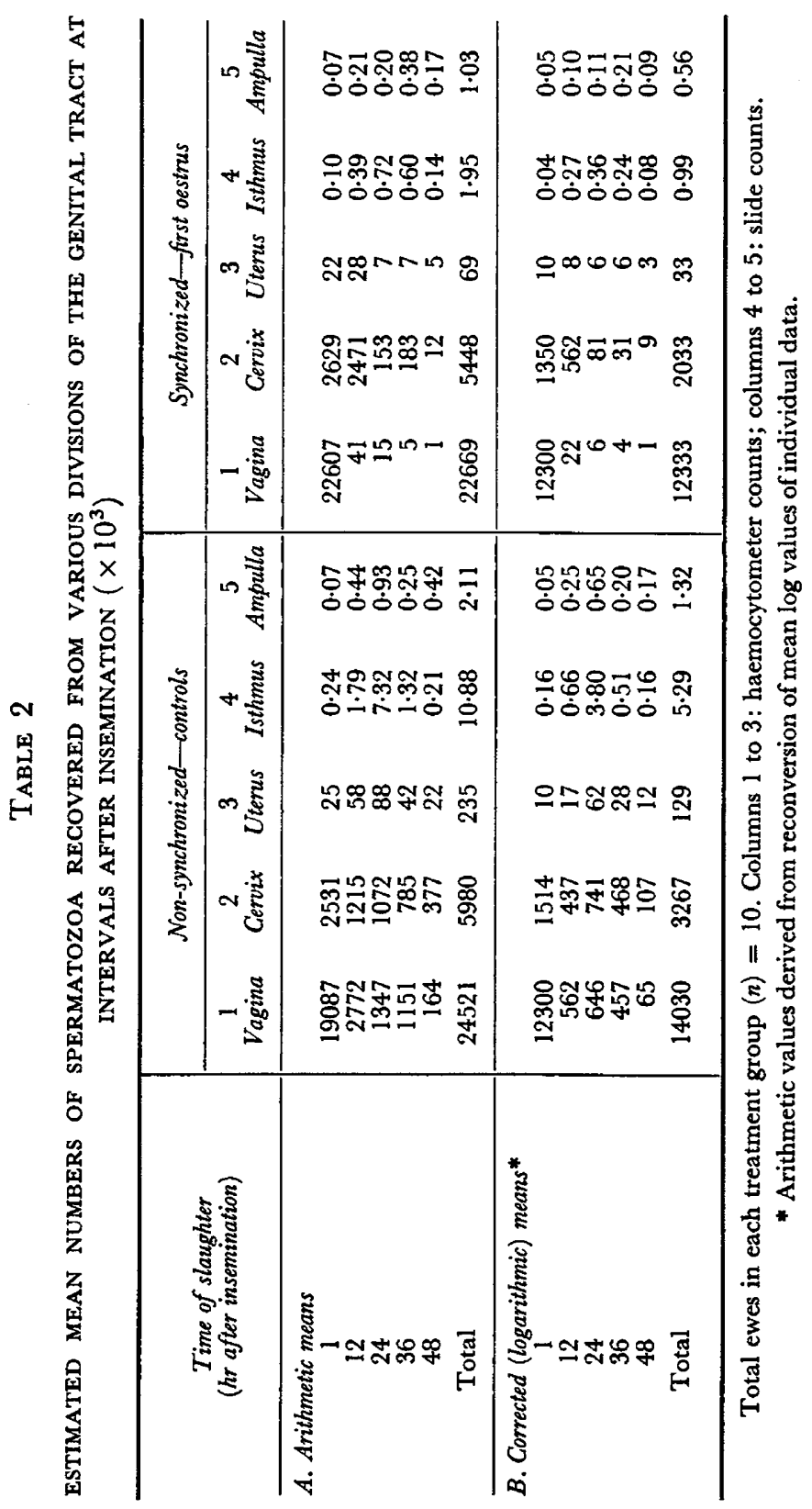


variance of the data for vagina, cervix and uterus. Analysis 1 is on the mean of six counts for each ewe, and Analysis 2 is on one count only, selected at random. Both analyses are presented as an index of precision of technique. Use of all six counts reduces the error associated with counting by approximately one-half. Thus a six-fold increase in counting time results in only a doubling of precision and does not affect any conclusions.

One hour after insemination, the pattern of distribution of spermatozoa in the genital tract of synchronized and non-synchronized ewes was indistinguishable except for the isthmus, where larger numbers appeared in the latter

TABLE 3

ANALYSES OF VARIANCE OF DATA FOR SPERMATOZOA RECOVERED FROM VAGINA, GERVIX AND UTERUS FOLLOWING LOG TRANSFORMATION

\begin{tabular}{|c|c|c|c|c|c|}
\hline \multirow{2}{*}{ Source of variation } & \multirow{2}{*}{$\begin{array}{l}\text { Degrees } \\
\text { of } \\
\text { freedom }\end{array}$} & \multicolumn{2}{|c|}{ Mean square $\dagger$} & \multicolumn{2}{|c|}{$F \dagger$} \\
\hline & & Analysis 1 & Analysis 2 & Analysis 1 & Analysis 2 \\
\hline $\begin{array}{l}\text { Main plots } \\
\text { Synchronization of oestrus } \\
\text { Time of flushing } \\
\text { Synchronization } \times \text { time } \\
\text { Within (Error) }\end{array}$ & $\begin{array}{r}1 \\
4 \\
4 \\
90\end{array}$ & $\begin{array}{r}88 \cdot 39 \\
75 \cdot 32 \\
10 \cdot 28 \\
1 \cdot 28\end{array}$ & $\begin{array}{r}72 \cdot 80 \\
54 \cdot 03 \\
7 \cdot 49 \\
2 \cdot 12\end{array}$ & $\begin{array}{c}69 \cdot 05^{* * *} \\
58 \cdot 84^{* * *} \\
8 \cdot 03^{* * *}\end{array}$ & $\begin{array}{c}34 \cdot 34 * * * \\
25 \cdot 49 * * * \\
3 \cdot 79 * *\end{array}$ \\
\hline $\begin{array}{l}\text { Sub-plots } \\
\text { Division of tract } \\
\text { Division } \times \text { synchronization } \\
\text { Division } \times \text { time } \\
\text { Division } \times \text { synchronization } \times \text { time } \\
\text { Within (Error) }\end{array}$ & $\begin{array}{r}2 \\
2 \\
8 \\
8 \\
180\end{array}$ & $\begin{array}{r}157 \cdot 82 \\
24 \cdot 00 \\
23 \cdot 54 \\
2 \cdot 54 \\
1 \cdot 11\end{array}$ & $\begin{array}{r}110.57 \\
19.13 \\
17.04 \\
1.65 \\
1.85\end{array}$ & $\begin{array}{c}142 \cdot 18^{* * *} \\
21 \cdot 62 * * * \\
21 \cdot 21^{* * *} \\
2 \cdot 29 *\end{array}$ & $\begin{array}{l}59 \cdot 77 * * * \\
10 \cdot 34 * * * \\
9 \cdot 21 * * * \\
0 \cdot 89\end{array}$ \\
\hline Total & 299 & & & & \\
\hline
\end{tabular}

$* P<0.05 ; \quad * * P<0.01 ; * * * P<0.001$.

$\dagger$ Analysis 1 . Total data using means of counts for six slides for each sheep. Analysis 2. Data for one slide selected at random for each sheep.

animals. By $12 \mathrm{hr}$, distinct differences had become apparent and these increased over the next $12 \mathrm{hr}$ (Text-fig. 1). Overall, there were highly significant differences in numbers of spermatozoa recovered attributable to synchronization of oestrus, time of slaughter and division of the genital tract $(P<0.001)$, together with significant interactions between these factors $(P<0.05$ to $P<0.001)$.

There was a much more rapid decline with time in the total numbers of spermatozoa recovered from synchronized than from non-synchronized ewes (Text-fig. 2).

Individual analyses of variance of data for each division of the genital tract showed significant effects of synchronization $(P<0.01$ to $P<0.001)$ and time of flushing $(P<0.05$ to $P<0.001)$ on the numbers of spermatozoa recovered. There were also interactions between synchronization and time which, except in the case of the ampulla, attained significance $(P<0.05$ to $P<0.001)$. These characteristics are illustrated in Text-fig. 3.

Vagina. At $1 \mathrm{hr}$, the numbers of spermatozoa recovered from the vagina of synchronized and non-synchronized ewes were indistinguishable (Table 2). 


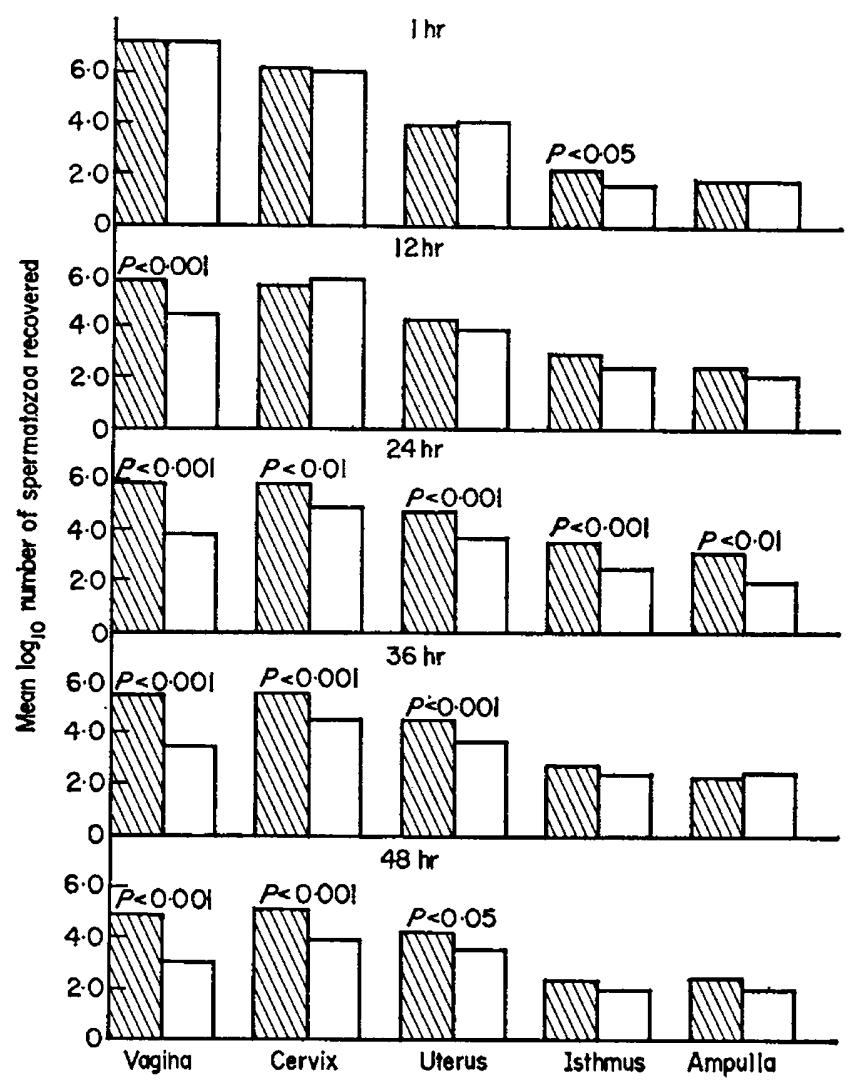

TEXT-FiG. 1. Estimated mean number of spermatozoa recovered from different divisions of the genital tract at each time of slaughter. Hatched columns: non-synchronized (controls); open columns: synchronized.

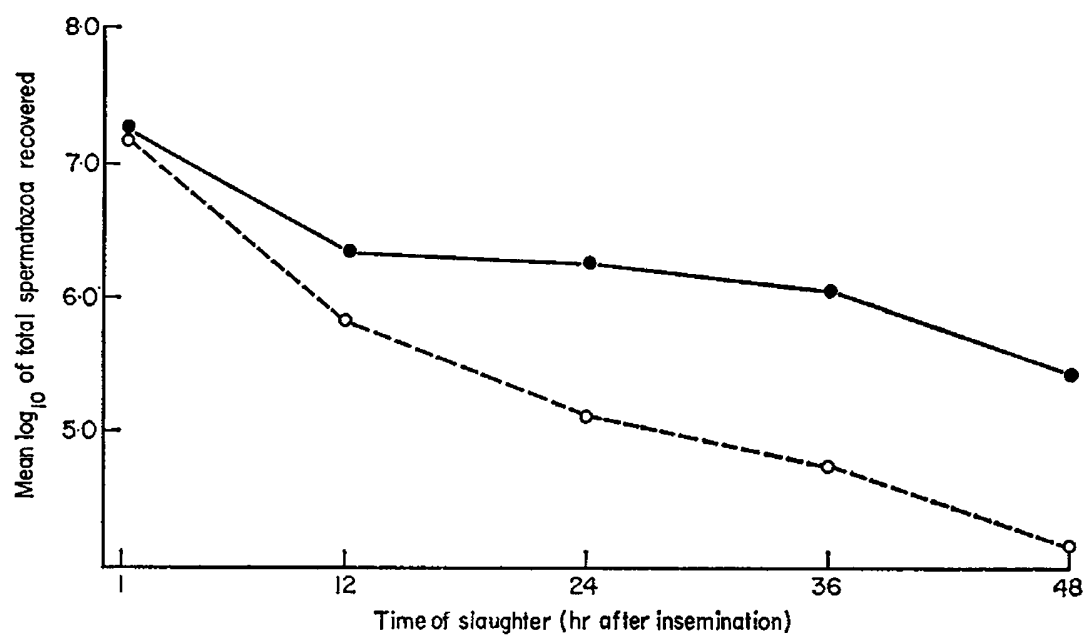

TEXT-FIG. 2. Estimated mean numbers of spermatozoa recovered from the entire reproductive tract at intervals after insemination $(n=10, \mathcal{N}=100)$. $\bullet$, Non-synchronized (controls); 0 , synchronized. 
Thereafter, the numbers fell much more rapidly in the synchronized than in the non-synchronized ewes $(P<0.001)$ and the pattern of decline differed significantly (Text-fig. 3a).

In non-synchronized ewes the decline was not simply a linear function of time, as shown by the highly significant quadratic and cubic components of the time effect $(P<0 \cdot 001)$ and the significant interaction between synchronization

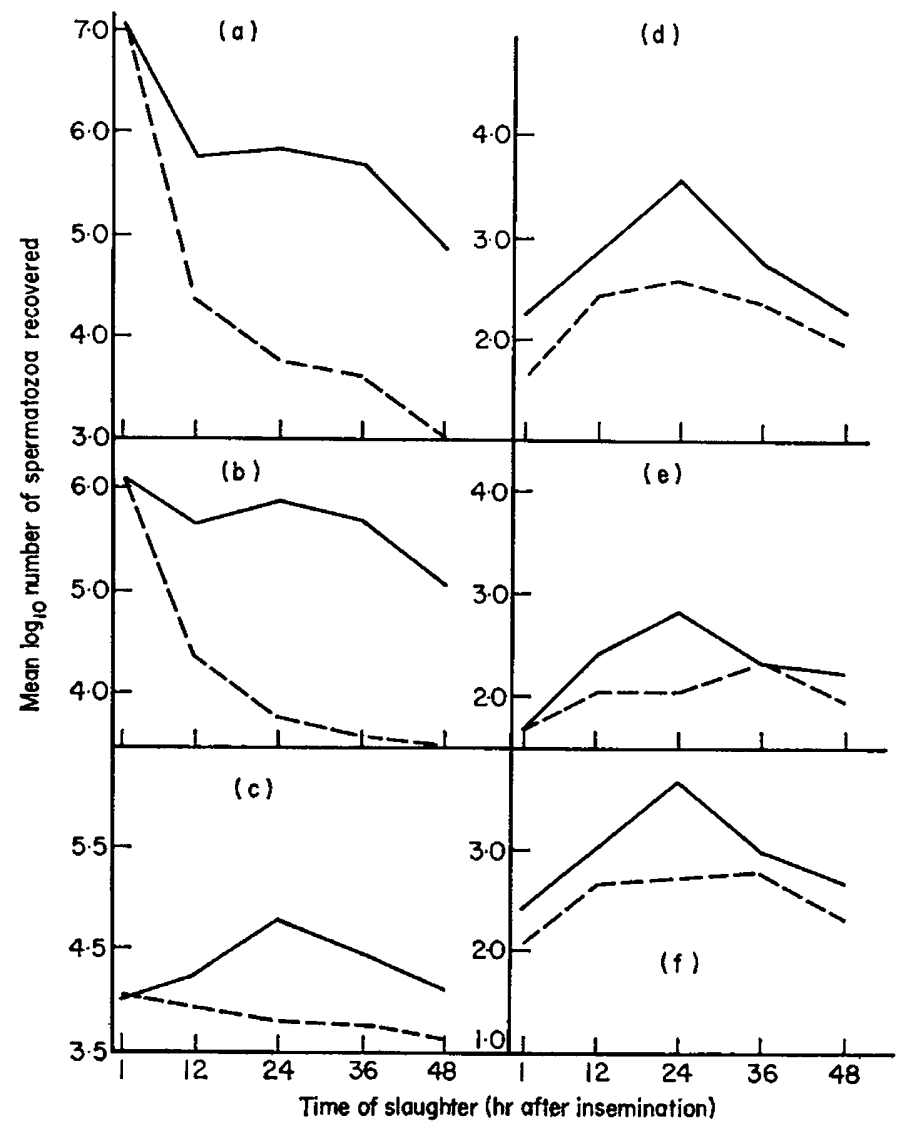

TExT-FIG. 3. Estimated mean number of spermatozoa recovered from various regions of the tract at intervals after insemination. - - Non-synchronized (controls); - - - , synchronized. (a) Vagina; (b) cervix; (c) uterus; (d) isthmus; (e) ampulla; (f) total Fallopian tubes.

and time: quadratic $(P<0.001)$. Following an initial large decline between 1 and $12 \mathrm{hr}$, the numbers remained high until $36 \mathrm{hr}$ after insemination and then fell rapidly again to $48 \mathrm{hr}$.

In synchronized ewes the pattern was quite different. Following an initial fall, larger than in non-synchronized animals between 1 and $12 \mathrm{hr}$, there was no maintenance of the vaginal population which continued to fall away, although at a slower rate.

Cervix. Maximum numbers of spermatozoa appeared in the cervical flushings at $1 \mathrm{hr}$ after insemination, when the numbers recovered were indistinguishable 
in synchronized and non-synchronized ewes (Table 2). Thereafter the pattern was similar for both classes of ewe to that observed for the vagina (Text-fig. $3 a, b)$.

In non-synchronized ewes the cervical population remained high until 36 $\mathrm{hr}$ and was still substantial at $48 \mathrm{hr}$.

In synchronized ewes the numbers fell much more rapidly $(P<0.001)$ and, following the initial large fall between 1 and $12 \mathrm{hr}$, there was no maintenance of a cervical population in the majority of animals.

Uterus. At $1 \mathrm{hr}$, the numbers of spermatozoa recovered from the uterus of synchronized and non-synchronized ewes were indistinguishable (Table 2), but thereafter the pattern was markedly different (Text-fig. 3c).

In non-synchronized ewes, there was a linear increase in mean numbers until $24 \mathrm{hr}$ after insemination, followed by a linear decline to $48 \mathrm{hr}$.

In synchronized ewes, there was no such increase to $24 \mathrm{hr}$, but a steady decline. This difference was significant as shown by the significant quadratic component of the time effect $(P<0.05)$ and the significant interaction between synchronization and time: quadratic $(P<0 \cdot 05)$.

Isthmus, ampulla and total Fallopian tubes. The patterns in the segments of the tube were essentially similar and, in the non-synchronized but not in the synchronized ewes, closely mirrored changes in the uterus (Text-fig. $3, \mathrm{~d}, \mathrm{e}, \mathrm{f}$ ).

In non-synchronized ewes, there was a linear increase in mean numbers until $24 \mathrm{hr}$, followed by a linear decline to $48 \mathrm{hr}$.

In synchronized ewes, there was a slow increase to $36 \mathrm{hr}$-at which time the numbers were comparable to those in untreated ewes-followed by a decline. The overall difference between the two classes of ewe was highly significant $(P<0.001)$ as was the pattern of increase and decrease $(P<0.001)$. The different pattern of accumulation of spermatozoa with time after insemination, as shown by the interaction between synchronization and time: quadratic, attained significance in the ampulla and total tube counts $(P<0.05)$.

\section{Distribution between animals of numbers of spermatozoa recovered}

There was an enormous variation in the number of spermatozoa recovered between animals within treatments. This is reflected by the differences between the arithmetic and logarithmic means in Table 2, and is illustrated for the Fallopian tubes in Text-fig. 4, in which the distributions are essentially similar to those reported earlier (Quinlivan \& Robinson, 1967).

Correlations between numbers of spermatozoa recovered from various divisions of the genital tract

Correlation coefficients were calculated for the numbers of spermatozoa recovered from successive regions of the tract at successive time intervals. No clear pattern was evident.

Four positive correlations-two significant $(P \leqslant 0.05)$ and two near significant $(P<0 \cdot 10)$-occurred in the non-synchronized ewes. These were vagina-cervix at $1 \mathrm{hr}(\mathrm{r}=0.64 ; P<0.05)$ and $36 \mathrm{hr}(\mathrm{r}=0.59 ; P<0.10)$, cervix-uterus at 12 $\mathrm{hr}(\mathrm{r}=0.63 ; P=0.05)$ and uterus-tubes at $1 \mathrm{hr}(\mathrm{r}=0.57 ; P<0.10)$.

Two negative and one positive correlation-one significant $(P=0.05)$ and 
two near-significant $(P \leqslant 0 \cdot 10)$-occurred in the synchronized ewes. These were vagina-cervix at $1 \mathrm{hr}(\mathrm{r}=-0.61 ; P<0.10)$, cervix-uterus at $24 \mathrm{hr}(\mathbf{r}=-0.55$; $P=0 \cdot 10)$ and uterus-tubes at $12 \mathrm{hr}(\mathrm{r}=0.63 ; P=0.05)$.

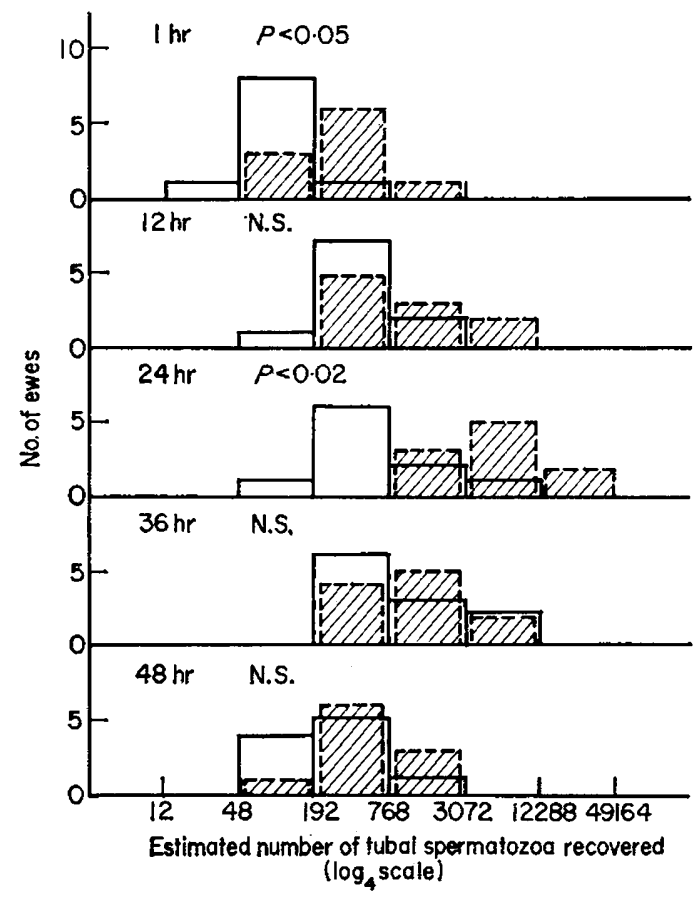

Text-FIG. 4. Distribution of number of ewes which yielded tubal spermatozoa, classed into intervals, at $1,12,24,36$ and $48 \mathrm{hr}$ after insemination. Hatched columns: nonsynchronized (controls); open columns: synchronized.

\section{DISCUSSION}

These results confirm and extend those of Quinlivan \& Robinson (1967) in that treatment with Cronolone-impregnated intravaginal sponges altered the pattern of sperm transport at the first oestrus following sponge withdrawal, as compared with that in normal oestrous ewes. This difference was not due to insemination at a different stage of oestrus, as the ovarian state at the times of slaughter was indistinguishable between progestagen-treated and untreated control ewes, and the numbers of eggs recovered from the tubes were similar.

The data raise two basic considerations. First, they confirm the effect of progestagen treatment on the transport and survival of spermatozoa in the genital tract, and secondly they elaborate upon the observations of Quinlan, Maré \& Roux (1933) and Mattner (1963) on the pattern of sperm transport in the normal cyclic ewe.

Previous studies have indicated that successful sperm transport in the normal ewe is achieved by several events which follow coitus. There is the rapid establishment of reservoirs within the tract, presumably in the cervix (Mattner, 1966), followed by a gradual release of spermatozoa so that adequate numbers 
are available in the Fallopian tubes at the time of ovulation and fertilization. These concepts have been confirmed in this study with untreated cyclic sheep.

The importance of the vagina as a reservoir has not been defined. Evidence that it may play some role immediately after service has been provided by Krebhiel \& Carstens (1939) and Akester \& Inkster (1961), who demonstrated that minute jets of radio-opaque fluid passed through the cervices of the rabbit doe during vaginal contractions. Although Noyes, Adams \& Walton (1958) and Edgar \& Asdell (1960) were unable to confirm this, they reported that radio-opaque media appeared to be forced against the cervix by vaginal contractions.

Our data support the view that the cervix is an important reservoir for spermatozoa. The rapid decline in cervical numbers between 1 and $12 \mathrm{hr}$ after insemination must play a significant role in the establishment of adequate populations in the uterus and Fallopian tubes. Further, the stability of the cervical population between 12 and $24 \mathrm{hr}$ probably involves replenishment over this period, for which the vagina is the only source. During this period the populations in the uterus and the Fallopian tubes are steadily increasing to their maximum at $24 \mathrm{hr}$.

The establishment of reservoirs other than in the cervix could be anticipated. Table 2 provides evidence that the isthmus may act as a reservoir for the ampulla in the normal ewe. It is estimated that twice as many spermatozoa were present in the isthmus as in the ampulla at $1 \mathrm{hr}$, and that at 12, 24 and 36 $\mathrm{hr}$ this ratio was five, eight and four to one. At $48 \mathrm{hr}$, the population in the isthmus appeared almost exhausted, probably because of failure of replenishment from the uterus. By analogy with results obtained on laboratory animals, it is generally accepted for the ewe that the isthmus, rather than the utero-tubal junction, constitutes a barrier to the free progression of spermatozoa. This is considered due to the smaller diameter of the lumen, the extensive folding of the mucosa, and the presence of forceful muscular contractions at oestrus (Greenwald, 1963). It is not difficult to visualize that the isthmus may act as a reservoir for the ampulla in much the same manner as does the cervix, and possibly the vagina, for the uterus.

The physiological reasons for the steady increase in sperm numbers in the uterus and the Fallopian tubes up to $24 \mathrm{hr}$ after insemination of the normal oestrous ewe have not been defined. Whatever the mechanisms involved, it appears that maximum chances of successful fertilization depend upon such a pattern of accumulation (Quinlivan \& Robinson, 1967).

Spermatozoa may be lost from the genital tract in three ways: first, by voidance to the exterior from the vagina (Blandau \& Odor, 1949; Austin, 1957; Reid, 1965a, b); secondly, by passage into the peritoneal cavity (Edgar \& Asdell, 1960; Horne \& Thibault, 1962; Mattner \& Braden, 1963); and thirdly, by phagocytosis within the tract (Chang, 1956; Austin, 1957, 1959; Bedford, 1965; Reid, 1965a; Haynes, 1967).

Comparison of the patterns shown by non-synchronized (normal oestrus) and synchronized ewes (Text-figs. 2 and 3 ) suggests that two mechanisms are involved in the rapid disappearance of spermatozoa from the vagina within the first $12 \mathrm{hr}$ of insemination. A substantial cervical population is established 
rapidly, within $1 \mathrm{hr}$, and, as shown by Text-fig. 2, it is not possible to account for the vaginal loss by compensatory numbers further up the tract. Hence spermatozoa are either destroyed and resorbed in situ or are voided to the exterior. It is difficult to attribute the huge difference between the two classes of ewes to differing rates of voidance of unwanted spermatozoa. The inescapable conclusion is that destruction and absorption in situ in the vagina is a normal phenomenon and that the rate of such destruction may be greatly accelerated in some physiological states, such as those which exist following synchronization of oestrus.

Most of the loss from the cervix in the normal sheep may be accounted for by forward movement into the uterus in the first stage of the development of the 24-hr peak in sperm population. After $12 \mathrm{hr}$, the various ways by which spermatozoa may be 'lost' from the genital tract may all play an additive role in the elimination of those spermatozoa not involved in fertilization. The overall effect, as shown in Table 2 and Text-fig. 2, is a linear decline with time in the $\log$ number of spermatozoa remaining in the tract.

The failure to demonstrate a meaningful series of significant correlations in the numbers of spermatozoa recovered from various sections of the tract is surprising, and may be related to sample size. The significant correlations between vagina and cervix at $1 \mathrm{hr}$ in normal ewes and between cervix and uterus at $12 \mathrm{hr}$ are almost certainly meaningful and emphasize the importance of the vagina in establishing a large cervical population and of the cervix in establishing an adequate uterine population. The existence of positive, albeit non-significant, correlations between uterine and tubal populations lends support to this concept.

The pattern of sperm transport and survival in the progestagen-treated animal differs substantially from that in the normal ewe. The rate of disappearance of spermatozoa is much more rapid than in normal animals and this process apparently begins within the first $12 \mathrm{hr}$ after service (Table 2, Textfig. 2). Text-figures 1 and 3 show the development of the pattern of difference. At $1 \mathrm{hr}$ the mean vaginal, cervical and uterine populations are indistinguishable. At $12 \mathrm{hr}$, the vaginal count in synchronized ewes is significantly depressed and at $24 \mathrm{hr}$, vaginal, cervical, uterine and tubal counts are all down significantly. The inability of the treated animals to maintain an adequate cervical population between 12 and $24 \mathrm{hr}$ appears to be a key factor in the failure to establish and maintain an adequate uterine and tubal population at $24 \mathrm{hr}$. This excessive disappearance of spermatozoa is due, presumably, to death and resorption rather than to any significant caudal or cranial shift and subsequent loss.

Smallwood \& Sorensen (1967) and Quinlivan (1967) demonstrated apparent histological abnormalities in the endometria of progestagen-treated cattle and sheep at the first post-withdrawal oestrus. These were characterized by the persistence of degenerative changes which seemingly follow the waning of the corpus luteum in the normal cycle or the sudden cessation of exogenous progestagen treatment. Further, the mobilization of excessive numbers of polymorphonuclear leucocytes underlying the basement membrane, was also demonstrated. Moore \& Robinson (1967) reported a high density of Corynebacteria and gram-negative bacilli in intravaginal sponges, particularly those inserted 
without any bactericide. Vaginal smears from treated ewes had an abundant flora, the nature of which was affected by the use of bactericides with the sponges. Subsequently, Quinlivan (1967) found high concentrations of Corynebacterium pyogenes and coliforms in the cervical mucus of treated sheep, due presumably to continual contamination of the sponge string by faeces and urine and the retention of an intravaginal foreign body. This may contribute to the depletion in sperm numbers in the genital tract, and particularly in the vagina.

Variable fertility is a feature of all forms of progestagen treatment for the control of the oestrous cycle. However, it is not an invariable feature and satisfactory fertility has been reported in some tests involving the use of intravaginal sponges (Robinson, 1965; Robinson, Quinlivan \& Baxter, 1968). One factor appears to be the amount of progestagen absorbed, indicating the need for further studies on the effect of endocrine status at oestrus on the pattern of sperm transport and survival. It should be possible to manipulate this status, and hence the pattern of accumulation of spermatozoa in the Fallopian tubes, so as to increase or decrease the chances of fertilization without affecting ovulation.

\section{ACKNOWLEDGMENTS}

Grateful acknowledgment is made to the Trustees of the McCaughey Memorial Institute, Jerilderie, for the provision of experimental animals and facilities; to Mr A. D. Barnes and Miss M. A. Hutchins for field and technical assistance; and to the management and staff of the abattoir at Finley, N.S.W.

One author (T.D.Q.) was holder of a Sir Walter Mulholland Fellowship awarded by the New Zealand University Grants Committee, Wool Board and Romney Association. Experimental materials were generously supplied by G. D. Searle and Co. (Aust.), Sydney. The work was supported by a grant from the Australian Research Grants Committee.

\section{REFERENCES}

Akester, A. R. \& INkSter, I. J. (1961) Cineradiographic studies of the genital tract of the rabbit. J. Reprod. Fert. 2, 507.

Anon. (1963) Ann. Rep. C.S.I.R.O., Anim. Res. Lab., Div. Anim. Physiol. 71.

Austin, C. R. (1957) Fate of spermatozoa in the uterus of the mouse and the rat. F. Endocr. 14, 335. Austriv, C. R. (1959) Entry of spermatozoa into the Fallopian tube mucosa. Nature, Lond. 183, 908.

BeDFord, J. M. (1965) Effect of environment on phagocytosis of rabbit spermatozoa. J. Reprod. Fert. 9, 249.

BLANDAU, R. J. \& ODOR, D. L. (1949) The total number of spermatozoa reaching various segments of the reproductive tract in the female albino rat at intervals after insemination. Anat. Rec. 103, 93.

Chang, M. C. (1956) Reaction of the uterus on spermatozoa in the rabbit. Annali Ostet. Ginec. 78, 74.

Edgar, D. G. \& Asdell, S. A. (1960). Spermatozoa in the female genital tract. F. Endocr. 21, 321.

GreEnWALd, G. S. (1963) In vivo recording of intralumenal pressure changes in the rabbit oviduct. Fert. Steril. 14, 666 .

Hancock, J. L. (1962) Fertilization in farm animals. Anim. Breed. Abstr. 30, 285.

HAYNEs, N. B. (1967) The influence of the uterine environment on the phagocytosis of spermatozoa. In: Reproduction in the Female Mammal, p. 500. Proc. 13th Easter School, Univ. Nottingham, 1966. Eds. G. E. Lamming and E. C. Amoroso. Butterworths, London.

Horne, H. W. \& Thibault, J. (1962) Sperm migration through the female reproductive tract. Fert. Steril. 13, 135. 
Krebhitel, R. H. \& Carstens, H. P. (1939) Roentgen studies of the mechanism involved in sperm transportation in the female rabbit. Am. F. Physiol. 125, 571.

MAtTner, P. E. (1963) Spermatozoa in the genital tract of the ewe. II. Distribution after coitus. Aust. 7. biol. Sci. 16, 688.

MATtNer, P. E. (1966) Formation and retention of the spermatozoan reservoir in the cervix of the ruminant. Nature, Lond. 212, 1479.

Mattner, P. E. \& Braden, A. W. H. (1963) Spermatozoa in the genital tract of the ewe. I. Rapidity of transport. Aust. F. biol. Sci. 16, 473.

MOORE, N. W. \& RoBinson, T. J. (1967) A comparison of progesterone-impregnated and non-impregnated intravaginal sponges treated with several bactericides. In: The Control of the Ovarian Cycle in the Sheep, p. 102. Ed. T. J. Robinson. Sydney University Press, Sydney.

Noyes, R. W., Adams, C. E. \& Walton, A. (1958) Transport of spermatozoa into the uterus of the rabbit. Fert. Steril. 9, 288.

Ožın, F. V. (1956) Artificial insemination in sheep. Sel'khozgiz., Leningrad.

Quinlan, J., MARE, G. S. \& Roux, L. L. (1933) A study of the duration of motility of spermatozoa in the different divisions of the reproductive tract of the Merino ewe. Onderstepoort 7. vet. Sci.1, 135.

Quinurvan, T. D. (1967) Sperm transport and fertilization in normal and progestagen-treated ewes. Ph.D. thesis, University of Sydney.

Quinlivan, T. D. \& RoBinson, T. J. (1967) The number of spermatozoa in the Fallopian tubes of ewes at intervals after artificial insemination following withdrawal of SC-9880 impregnated intravaginal sponges. In: The Control of the Ovarian Cycle in the Sheep, p. 177. Ed. T. J. Robinson. Sydney University Press.

Reid, B. L. (1965a) The fate of uterine spermatozoa in the mouse post coitum. Aust. F. Zool. 13, 189.

Reid, B. L. (1965b) The fate of isotope labelled uterine spermatozoa in the mouse post coitum. Aust. $\mathcal{F}$. Zool. 13, 525 .

RoBinson, T. J. (1965) Use of progestagen-impregnated sponges inserted intravaginally or subcutaneously for the control of the oestrous cycle in the sheep. Nature, Lond. 206, 39.

Robinson, T. J., Quinlivan, T. D. \& Baxter, C. (1968) The relationship between dose of progestagen and method of preparation of intravaginal sponges on their effectiveness for the control of ovulation in the ewe. F. Reprod. Fert. 17, 471.

Smallwood, G. M. \& Sorensen, A. M. (1967) Histological changes in the cow following progestins. 7. Anim. Sci. 26, 951. 